\title{
Решение Верховного суда США по делу «Самантар против Юсуфа» и иммунитеты иностранных должностных лиц
}

\section{Шаталова C.B.*}

Статья посвящена решению Верховного суда США от 1 июня 2010 г. по делу «Самантар против Юсуфа», в котором был авторитетно решен вопрос об источнике правовых норм, регулирующих иммунитеты иностранных должностных лиц в американском праве. До вынесения постановления различные федеральные апелляционные суды США по-разному трактовали вопрос о том, применим ли закон «Об иммунитете иностранных государств» 1976 г. к иностранных чиновникам, действующим в официальном качестве. В результате этой правовой неясности зарубежные правительственные служащие пользовались в американских судах различным объемом иммунитетов в практически идентичных ситуациях. Поскольку постановления Верховного суда обязательны для всех нижестоящих американских судов, дело сомалийского генерала М. Самантара вызвало большой резонанс в юридическом сообществе США, а также в ряде иностранных государств. В статье излагаются различные правовые позиции, которые были представлены суду адвокатами заявителя, ответчиков, правительственными юристами, а также третьими сторонами. Резюмируется аргументация суда и анализируется значение, которое июньское постановление может иметь для дальнейшего развития американского права иммунитетов.

Ключевые слова: юрисдикционные иммунитеты; иностранные официальные лица; общее право; иммунитет главы государства.

Несколько последних десятилетий между федеральными апелляционными судами США шел спор об источнике норм права, регулирующих юрисдикционные иммунитеты иностранных должностных лиц в американских судах. Одни судебные инстанции считали, что данный вопрос должен решаться на основании закона 1976 г. «Об иммунитете иностранных государств» (ЗИИГ)1, другие - на основе общего права.

\footnotetext{
* Шаталова Светлана Викторовна - третий секретарь Посольства России в США. taurussvet@hotmail.com

${ }^{1}$ Foreign Sovereign Immunity Act (FSIA). Кодифицирован в статьях 1330, 1602 и след. раздела 28 («Судебная система и судопроизводство») Свода законов США.
} 
От ответа на этот, казалось бы, технический вопрос зависело урегулирование многих субстантивных проблем: могут ли претендовать на иммунитет отставные чиновники, распространяются ли все исключения, предусмотренные законом 1976 г., на должностных лиц, и наоборот, могут ли существовать изъятия из иммунитетов чиновников, которые отсутствуют в ЗИИГ (например, исключение в отношении нарушений норм jus cogens).

1 июня 2010 г. Верховный суд США вынес постановление по делу «Самантар против Юсуфа» ${ }^{2}$, которое может положить конец царившим в прошлом разногласиям. Высшая судебная инстанция страны впервые имела возможность высказаться по поводу того, распространяется ли иммунитет иностранного государства по закону 1976 г. на его должностных лиц, действующих в официальном качестве, и если да, продолжает ли этот иммунитет действовать после того, как лицо покидает свой пост.

Дело дошло до Верховного суда США в результате прошения бывшего высокопоставленного сомалийского генерала М. Самантара. В 1980-1986 гг. (при режиме М. Сиада Барре) он занимал пост министра обороны и вице-президента Сомали, в 1987-1990 гг. - премьерминистра страны. После свержения военной диктатуры в 1991 г. он бежал из страны и в настоящее время проживает в США³.

В ноябре 2004 г. выходцы из Сомали подали гражданский иск против М. Самантара в федеральный окружной суд штата Вирджиния. Генерал обвиняется в том, что, находясь на высокопоставленных правительственных должностях, он санкционировал применение пыток, внесудебных казней и других нарушений прав человека по отношению к гражданскому населению, в первую очередь - к представителям оппозиционного сомалийского клана иса. Согласно истцам, в силу своего должностного положения он не мог не знать о злоупотреблениях своих подчиненных. Юридическим основанием для подачи иска

${ }^{2}$ Mohamed Ali Samantar v. Bashe Abdi Yousuf et Al., Supreme Court of the United States. On writ of Certiorari to the United States Court of Appeals for the Fourth Circuit. URL: http://www.supremecourt.gov/opinions/09pdf/08-1555.pdf.

${ }^{3}$ В конце 1970-х гг. США всячески поддерживали режим М.Сиада Барре, рассматривая его в качестве союзника в холодной войне. Сам генерал Самантар неоднократно приезжал в США, где его принимали такие высокопоставленные американские чиновники как вице-президент, госсекретарь, министр обороны, директор ЦРУ и председатель Объединенного комитета начальников штабов. 
против М. Самантара послужили законы «О деликтах, совершенных иностранцами» ${ }^{4} 1789$ г. и «О защите жертв пыток» ${ }^{5} 1991$ г.

Сразу же после возбуждения дела адвокаты М.Самантара подали в вирджинский суд ходатайство об отклонении иска, ссылаясь на судебный иммунитет бывшего генерала. В этой связи суд приостановил ход судебного разбирательства и обратился в Государственный департамент с просьбой высказать свое мнение по данному вопросу. Несмотря на двухгодичное молчание внешнеполитического ведомства, 1 августа 2007 г. окружной суд вынес постановление о своей некомпетентности рассматривать дело ${ }^{6}$.

При этом суд сослался на закон 1976 г., согласно которому иностранное государство пользуется иммунитетом от юрисдикции американских судов, если только соответствующий иск не подпадает под одно из исключений, перечисленных в этом нормативно-правовом акте.

В самом законе «Об иммунитете иностранных государств» прямо не указывается, относится ли он к иностранным должностным лицам, действующим в официальном качестве. Не дает он и четкого определения термина «иностранное государство». В пункте «а» статьи 1603 ЗИИГ лишь указывается, что этот термин включает политическое подразделение, а также агентство или орган иностранного государства, как те определены в пункте «b». В соответствии с последним «агентство или орган иностранного государства» означает образование: (1) которое является отдельным юридическим лицом, зарегистрированным в корпоративной или другой форме, (2) которое является органом иностранного государства или его политическим подразделением, либо бо́льшая часть акций или доля собственности которого находится во владении иностранного государства или его политического подразделения, и (3) которое не имеет национальности США, как то определено

\footnotetext{
${ }^{4}$ Alien Tort Statute (ATS). Устанавливает, что федеральные окружные суды обладают юрисдикцией в отношении любых гражданских исков, подаваемых иностранцами в связи с деликтами, совершенными в нарушение норм международного обычного права или международного договора США.

5 Torture Victim Protection Act (TVPA). Устанавливает федеральное основание для предъявления гражданского иска (при условии исчерпания внутренних средств правовой защиты) с целью получения компенсации от лица, которое с помощью своей действительной или видимой власти или под предлогом закона иностранного государства совершило пытки или внесудебные казни.

6 Yousuf v. Samantar, U.S. District Court for the Eastern District of Virginia, Division of Alexandria, 2007. URL: http://www.cja.org/downloads/Samantar_Opinion_106.pdf.
} 
в пунктах «с» и «е» статьи 1332 данного раздела, и которое не образовано в соответствии с законами любого третьего государства.

Согласно логике окружного суда, поскольку Самантару вменяются в вину действия, совершенные им в официальном качестве, а не по личным мотивам, ответчик подпадает под определение термина «агентство или орган государства» по смыслу ЗИИГ. При этом суд не согласился с аргументом истцов, что генерал явно превысил свои должностные полномочия, поскольку действовал в нарушение норм международного права. Такому выводу, по мнению вирджинских судей, противоречит письмо Переходного федерального правительства (ПФП) Сомали в поддержку Самантара.

В своем постановлении окружной суд основывался главным образом на двух судебных прецедентах: решениях федеральных окружных судов округа Колумбия 2006 г. по делу «Белхас против Ялона» ${ }^{7}$ и южного округа г. Нью-Йорк 2007 г. по делу «Матар против Дихтера» ${ }^{8}$. Оба были впоследствии подтверждены вышестоящими апелляционными судами 9 .

В первом из них американский суд признал наличие иммунитета на основании закона 1976 г. у израильского генерала М. Ялона по иску, касавшемуся бомбардировок гражданского населения в рамках военных акций Израиля против военизированной ливанской организации «Хезболла» в 1996 г; во втором - у бывшего директора израильской разведки по иску относительно планирования и осуществления бомбардировки жилого квартала в секторе Газа.

Тем не менее, решением от 9 января 2009 г. федеральный апелляционный суд четвертого округа отменил постановление окружного суда в пользу Самантара, заявив, что закон 1976 г. неприменим к отдельным официальным лицам иностранных государств, если те преследуются в личном качестве ${ }^{10}$.

Суд при этом признал, что большинство федеральных апелляционных инстанций придерживаются иной точки зрения. Наиболее часто цитируемым в американской судебной практике в этой связи

\footnotetext{
${ }^{7}$ Belhas v. Ya'alon, 466 F. Supp. 2 d 127 (D.D.C. 2006).

${ }^{8}$ Matar v. Dichter, 500 F. Supp. 2d 284 (S.D.N.Y. 2007).

${ }^{9}$ Belhas v. Ya'alon, 515 F.3d 1279 (D.C. Cir. 2008); Matar v. Dichter, 563 F.3d 9 (2d Cir. 2009).

${ }^{10}$ Yousuf v. Samantar, U.S. Court of Appeals for the Forth Circuit, 8 January 2009, URL: http://pacer.ca4.uscourts.gov/opinion.pdf/071893.P.pdf.
} 
является постановление федерального апелляционного суда девятого округа 1990 г. по делу «Чуидиан против Филиппинского национального банка» ${ }^{11}$.

В нем суд отказался ограничивать сферу применения закона 1976 г. лишь самими иностранными государствами и подведомственными им юридическими лицами, как того требовали В. Чуидиан и Госдепартамент. По мнению судьи Уолласа, «последствия такого ограничения, будь то отказ в иммунитете, как того требует Чуидиан, либо возвращение к применявшемуся до Закона 1976 г. общему праву, как того требует правительство, совершенно не соответствовали бы целям Закона» ${ }^{12}$. Последние, как отмечается в постановлении, заключались в лишении Госдепартамента его дискреционных полномочий по решению вопроса об иммунитете, а также во всеобъемлющей кодификации норм общего права об иммунитете иностранных государств.

Более того, непризнание применимости ЗИИГ к чиновникам привело бы, по мнению судьи Уолласа, к «полной отмене иммунитета иностранных государств, поскольку позволило бы истцам обходными путями достигать того, что Закон 1976 г. запретил им делать напрямую» ${ }^{13}$.

С другой стороны, принятие позиции правительства привело бы к своеобразной форме «судебного шопинга»: «Тяжущиеся, не уверенные во влиятельности и дипломатическом мастерстве иностранного государства, с которым они судятся, предпочитали бы подавать иски против чиновников в расчете на поддержку Госдепартамента, тогда как тяжущиеся в менее выгодном положении склонялись бы к подаче исков напрямую против иностранных государств на основании закона, так как суды сами толкуют его без вмешательства Госдепартамента» ${ }^{14}$.

Эту логику впоследствии поддержали федеральные апелляционные суды второго ${ }^{15}$, шестого ${ }^{16}$, пятого ${ }^{17}$ округов, а также округа Колумбия $^{18}$. В то же время федеральные апелляционные суды седьмого

${ }^{11}$ Chuidian v. Philippine National Bank, 912 F.2d 1095 (9th Cir. 1990). URL: openjurist. org/912/f2d/1095/chuidian-v-phillippine-national-bank-b-chuidian.

12 Там же. Пар. 45.

13 Там же. Пар.46.

${ }^{14}$ Там же. Пар.48.

${ }^{15}$ In Re Terrorist Attacks on September 11, 2001, 538 F.3d 71 (2d Cir. 2008).

${ }^{16}$ Keller v. Central Bank of Nigeria, 277 F.3d 811, 815 (6th Cir. 2002).

17 Byrd v. Corporacion Forestal y Industrial de Olancho S.A., 182 F.3d 380, 388 (5th Cir. 1999).

${ }^{18}$ El-Fadl v. Central Bank of Jordan, 75 F.3d 668, 671 (D.C. Cir. 1996). 
и отчасти (применительно к главам государств) одиннадцатого округов заняли «диссидентскую» позицию.

Первый в своем постановлении 2005 г. по делу «Энахоро против Абубакара» ${ }^{19}$ заявил, что традиционная аргументация противоречит тексту Закона 1976 г. Судья Т. Эванс при этом выразил озабоченность в связи с позицией, занятой большинством его коллег, согласно которым, если закон прямо не исключает физических лиц, то это будто бы означает, что он их включает ${ }^{20}$.

Еще раньше в постановлении по делу «Йе против Цзэминя» 2004 г.21 этот же суд опроверг применимость ЗИИГ к главам государств. Истцами в нем выступали члены религиозно-духовного движения «Фалуньгун», которые обжаловали репрессивную политику Председателя КНР и Коммунистической партии Китая в отношении последователей учения, включая применение к ним пыток, незаконное заключение под стражу и геноцид.

В октябре 2002 г., накануне официального визита Ц. Цзэмина в США, истцы подали в федеральный суд ходатайство с просьбой разрешить им вручить китайскому главе государства судебную повестку о возбуждении гражданского иска против него самого и Управления по контролю за «Фалуньгун». Суд удовлетворил их прошение, и тяжущиеся вручили копию иска чикагскому полицейскому, охранявшему Ц. Цзэминя. В отсутствие какой-либо реакции со стороны китайского лидера, они подали в суд очередное ходатайство - на этот раз о регистрации неявки ответчика. На этой стадии в дело вмешался Госдепартамент, заявивший о наличии у Председателя КНР судебного иммунитета и личной неприкосновенности. После этого суд отказался удовлетворять иск.

Федеральный апелляционный суд седьмого округа подтвердил данное решение. По его мнению, ЗИИГ не касается иммунитета иностранных глав государств 22 , который по-прежнему относится к компетенции исполнительной власти. Госдепартамент недвусмысленно высказал свое мнение о наличии у Ц. Цзэмина иммунитета, и оно является обязательным для суда.

${ }^{19}$ Enahoro v. Abubakar, 408 F.3d 877, 881-82 (7th Cir. 2005). URL: openjurist.org/408/ F.3d/877/enahoro-cd-mko-v-abubakar.

${ }^{20}$ Там же. Пар.23.

${ }^{21}$ Ye v. Zemin, 383 F.3d 620 (7th Cir.2004), URL: openjurist.org/383/f3d/620/ye-v-zemin.

22 Там же. Пар.16 постановления. 
Апелляционный суд одиннадцатого округа, в свою очередь, заявил о неприменимости ЗИИГ к главам государств в решении по делу «США против Норьеги» 23.

Рассматривая апелляцию Самантара, апелляционный суд четвертого округа пришел к аналогичному выводу ${ }^{24}$. По мнению судьи Трэкслера, текст и общая структура ЗИИГ говорят о его неприменимости к физическим лицам. Так, например, статья о порядке вручения судебных повесток ответчикам практически дословно повторяет положение Федеральных правил гражданского судопроизводства о вручении судебных повесток организациям.

Подтверждение своей позиции суд нашел и в подготовительных материалах к закону. Так, в докладе профильного комитета Палаты представителей ${ }^{25}$ США 1976 г. говорится, что фраза «отдельные юридическое лицо» подразумевает «корпорацию, ассоциацию, фонд или любую другую организацию, которая в соответствии с законодательством иностранного государства, в котором она была создана, имеет право от своего имени подавать иски и отвечать по судебным искам, заключать контракты и владеть собственностью».

В заключении судья Трэкслер отметил, что, даже если бы закон 1976 г. был применим к должностным лицам, действующим в официальном качестве, он все равно бы не предоставлял защиту отставным чиновникам. При этом он сослался на решение Верховного суда США 2003 г. по делу «Доул Фуд Корпорейшн против Патриксона» 26. Согласно ему статус «агентства или органа иностранного государства» по смыслу закона 1976 г. должен определяться на момент подачи иска, а не на момент оспариваемых событий. Следовательно, если считать, что должностные лица иностранного государства входят в понятие «агентство или орган», их статус также должен определяться на момент начала судебного разбирательства.

На основании вышеперечисленных аргументов апелляционный суд отменил решение окружного суда в пользу Самантара и отправил дело на пересмотр. Не дожидаясь нового решения суда первой инстанции, в июне 2009 г. ответчик подал петицию в Верховный суд об истребовании своего дела в порядке надзора.

${ }^{23}$ United States of America v. Noriega, 117 F.3d 1206 (11th Cir. 1997).

${ }^{24}$ Yousuf v. Samantar, U.S. Court of Appeals for the Forth Circuit. P. 16.

${ }^{25}$ House of Representatives Report No. 94-1487 (1976).

${ }^{26}$ Dole Food Co. v. Patrickson, 538 U.S. 468 (2003). 
В петиции заявителя делается упор на то, что в случае вступления в силу постановления апелляционной инстанции, американская судебная система будет завалена исками, оспаривающими правомерность действий иностранных должностных лиц. Это, мол, нанесет урон международным отношениям США, подвергнет риску американских должностных лиц за границей и, помимо прочего, полностью выхолостит закон 1976 г.

Согласно заявителю, ЗИИГ принимался с целью кодифицировать прецедентное право в области иммунитетов иностранных государств. Это право, в свою очередь, исходило из понимания, что «действия официальных представителей государства - это действия самого государства, если они не выходят за рамки делегированных полномочий...» 27. Сам Верховный суд США в решении 1918 г. ${ }^{28}$ пришел к заключению, что действия «должным образом уполномоченного военного командира» являлись, по сути, «действиями легитимного мексиканского правительства».

Признав, что физических лиц можно включить в понятие «агентство или орган иностранного государства», как оно определяется в ЗИИГ, лишь с большой натяжкой, защитники Самантара предложили рассматривать их как неотъемлемую часть самого иностранного государства. Иное толкование закона, по их мнению, лишило бы его всякого смысла, поскольку в таком случае, чтобы обойти его, достаточно было бы просто назвать в качестве ответчика не само иностранное государство, а должностных лиц, с помощью которых оно действовало.

Что же касается бывших чиновников, то ссылка апелляционного суда четвертого округа на якобы прецедентное постановление по делу «Доул Фуд Корпорейшн против Патриксона» некорректна, поскольку, как объяснялось раньше, вышеупомянутое дело касалось статуса агентств или органов иностранных государств, тогда как в настоящей тяжбе речь идет о должностных лицах, являющихся частью самого иностранного государства.

Согласно ответному меморандуму оппонентов Самантара, заявитель попытался искусственно расширить сферу охвата закона «Об иммунитете иностранных государств». При этом ему не на что было опереться в самом тексте закона, формулировки и структура которого явно указывают на его неприменимость к физическим лицам. Поэтому

${ }^{27}$ Underhill v. Hernandez, 65 F. 577, 579 (2d Cir. 1895).

${ }^{28}$ Oetjen v. Cent. Leather Co., 246 U.S. 297, 303 (1918). 
адвокаты Самантара попытались убедить Суд, что, раз Конгресс прямо не запретил распространять его действие на должностных лиц, то он разрешил это.

С их точки зрения, ссылки заявителя на международное право как необходимый «контекст» для интерпретации ЗИИГ, в принципе, безосновательны: американские суды предоставляют иммунитет иностранным государствам на основе вежливости, а не обычного права. В этой связи Конгресс обладает безусловным правом отступать от международно-правовых стандартов.

Вместе с тем даже международное право далеко не всегда приравнивает иммунитет иностранных должностных лиц к иммунитету самих государств. В соответствии с международной практикой чиновники пользуются иммунитетом государства только в тех случаях, когда поданный против них иск затрагивает интересы этой станы (например, если компенсация, которую суд может присудить истцам, должна будет выплачиваться из госказны).

Дело «Самантар против Юсуфа» вызвало большой резонанс в юридических и общественных кругах США, а также в ряде иностранных государств, чьи должностные лица часто становятся мишенью гражданских исков в американских судах. В итоге Верховному суду были представлены полтора десятка заявлений amicus curiae ${ }^{29}$. Наряду с чисто правовыми аргументами, в них излагались исторические, политические и этические доводы в поддержку позиций заявителя или ответчиков.

Только четыре документа от «друзей суда» поддержали позицию Самантара: на его стороне выступили бывшие министры юстиции США, ряд произраильских организаций и Саудовская Аравия.

Главный тезис отставных руководителей американского Минюста - судебный иммунитет от иностранной гражданской юрисдикции позволяет представителям исполнительной власти принимать трудные, но необходимые решения, не опасаясь того, что впоследствии им будет грозить ответственность по законодательству иностранных государств.

Минюстовцы раскритиковали тезис о том, что вопрос об иммунитете иностранных должностных лиц должен решаться Госдепартаментом, а не судами. В таком случае предоставление иммунитета американским чиновникам за границей также зависело бы от мнения иностранных правительств. При этом не исключено, что последние

29 Доступны на веб-сайте: http://www.scotuswiki.com/index.php?title=Samantar_v._ Bashe_Abdi_Yousuf. 
не захотели бы вставать на защиту непопулярных, но необходимых действий американских должностных лиц.

Согласно заявлению amicus curiae, подготовленному рядом еврейских организаций, подтверждение Верховным судом постановления в пользу сомалийских истцов спровоцировало бы подачу в американские суды множества необоснованных исков против израильских должностных лиц в рамках т.н. «юридической войны», которая уже давно ведется против Израиля в ряде стран, включая Бельгию, Швейцарию, Новую Зеландию, Великобританию, Данию, Испанию, Голландию, Канаду и США ${ }^{30}$.

Отдельно в защиту позиции отставного сомалийского генерала выступил «Еврейский конгресс США», согласно которому в деле Самантара апелляционный суд ошибочно анализировал лишь текст и структуру самого ЗИИГ, не учитывая общий контекст международного права.

Между тем, суды многих государств признают, что иски против иностранных чиновников являются «практическим эквивалентом» исков против самих иностранных государств. Так, например, британская Палата лордов в постановлении 2006 г. по делу «Джонс против Саудовской Аравии» признала судебный иммунитет саудовских госслужащих по гражданскому иску, касавшемуся применения пыток. При этом она сослалась на множество иностранных прецедентов и на проекты статей КМП о юрисдикционных иммунитетах государств и их собственности. Принятая на их основе Конвенция $\mathrm{OOH}^{31}$ прямо включает «представителей государства, действующих в этом качестве» в определение термина «государство».

Отмечая, что британский закон «Об иммунитете государств» 1978 г. прямо не говорит о его применимости к должностным лицам, Лорд Бингэм заявил: «Существует, однако, множество авторитетных источников, доказывающих, что в таких случаях иностранное государство вправе требовать иммунитет для своих служащих, как если бы иск был подан против него самого» ${ }^{32}$.

«Еврейский конгресс США» также провел аналогию с американскими госслужащими, которые защищены от исков в отношении

30 Согласно докладу, опубликованному 12 октября 2009 г. в журнале "The National", по всему миру против израильских военных и чиновников была подана почти тысяча судебных исков по обвинению в военных преступлениях.

31 Принята резолюцией ГА ООН 2004 г. A.Res./59/38. Пока не вступила в силу.

32 Jones v. Ministry of Interior Al-mamlaka Al-Arabiya AS Saudia (the Kingdom of Saudi Arabia), House of Lords, Appellate Committee, 14 June 2006, [2006] UKHL 26. Пap. 10. 
правонарушений, совершенных ими при исполнении официальных функций, законом «О реформе гражданско-правовой ответственности федеральных служащих и компенсации за правонарушения» 1988 г. На его основании федеральный апелляционный суд округа Колумбия дважды подтверждал решение нижестоящего суда по делу «Расул против Майерса» ${ }^{33}$ об отказе в удовлетворении иска британских граждан бывших заключенных тюрьмы на военно-морской базе в Гуантанамо - против министра обороны США Д. Рамсфелда и десятерых высокопоставленных американских военных чиновников в связи с нарушением ими положений законодательства о запрете пыток и свободе вероисповедания.

В защиту позиции Самантара выступила и Саудовская Аравия, которая обосновала свой интерес в данном деле тем, что несколько лет назад американские суды были завалены многочисленными гражданскими исками против нее самой и ряда ее высокопоставленных должностных лиц, объединенными впоследствии в дело «О терактах 11 сентября 2001 г.».

В августе 2008 г. апелляционный суд второго округа признал наличие судебного иммунитета у самой Саудовской Аравии и наиболее высокопоставленных чиновников ${ }^{34}$. Тем не менее, иски против других должностных лиц Королевства по-прежнему находятся на рассмотрении в американских судах. Из опасения, что судебные тяжбы и в дальнейшем будут использоваться, чтобы ставить Саудовскую Аравию «в неудобное положение», это государство решило представить суду свою аргументацию в поддержку заявителя.

Однако гораздо больше документов от «друзей суда» было подано в поддержку ответчиков. Среди них - официальное заявление правительства США. Его основной тезис - именно принципы, сформулированные исполнительной властью (по сути, Госдепартаментом), а не ЗИИГ, надлежащим образом регулируют функциональный иммунитет иностранных должностных лиц от гражданских исков.

Традиционная практика судей запрашивать мнение исполнительной власти о наличии иммунитета в конкретных делах проистекает из конституционной прерогативы Госдепартамента решать чувствительные дипломатические и внешнеполитические вопросы. В этой связи не следует интерпретировать ЗИИГ как отменяющий эту практику sub silentio.

33 Rasul v. Myers, 563 F.3d 527 (D.C. Cir. 2009).

34 In Re Terrorist Attacks of September 11, 2001, 538 F.3d 71 (2d Cir. 2008). 
Более того, соответствующие решения должны приниматься с учетом слишком многих факторов (места жительства ответчика, серьезности вменяемых ему преступлений, положения истцов, позиции иностранного правительства, взаимности этого правительства в предоставлении иммунитетов американских должностным лицам и т.д.), чтобы соответствующий алгоритм можно было втиснуть в жесткие рамки закона.

Как отметили в своем заявлении amicus curiae американские профессоры международного публичного права и сравнительного правоведения, применявшееся до принятия ЗИИГ общее право не предоставляло абсолютный иммунитет от личной гражданской ответственности иностранным должностным лицам в отношении их официальных деяний, особенно если соответствующие акты нарушали общепризнанные нормы международного права. Так, в 1841 г. Верховный суд шт. НьюЙорк отказал в иммунитете бывшему заместителю шерифа Ниагарского округа Канады А. Маклеоду, который участвовал в нападении на американский пароход «Каролина» даже несмотря на подтверждение британского посла в США, что атака была произведена по приказу руководства и в рамках службы Ее Величеству 35 .

В меморандуме профессоров далее отмечается, что в международном праве различаются иммунитеты иностранных должностных лиц, основанные на статусе (иммунитеты ratione personae), и те, что основаны на природе защищаемых действий (иммунитеты ratione materiae). Первые доступны дипломатам, главам государств, а также узкому классу действующих высокопоставленных чиновников, включая министров иностранных дел. На вторые, в принципе, могут ссылаться все иностранные представители, независимо от того, занимают ли они пост в настоящий момент или нет. Однако, «хотя некоторые иностранные суды признавали наличие определенных иммунитетов у иностранных должностных лиц, не являющихся дипломатами, консулами и действующими главами государств, они делали это непоследовательно и, как правило, в рамках исков, в которых иностранное государство являлось либо реальной, либо необходимой стороной дела» ${ }^{36}$. Ввиду ма-

35 People v. McLeod, 25 Wend. 483 (N.Y. Sup. Ct. 1841). С помощью парохода «Каролина» американцы поставляли оружие восставшим против британской короны канадским повстанцам во главе с У. Маккензи.

${ }^{36}$ Mohamed Ali Samantar v. Bashe Abdi Yousuf, et al. Brief of the Professors of Public International Law and Comparative Law as Amici Curiae, in Support of Respondents. P. 16. 
лочисленности и непоследовательности этих решений из них нельзя вывести норму обычного международного права, основанную на постоянной практике и opinio juris.

В поддержку ответчиков выступили и американские эксперты в области международного судопроизводства и права международных отношений. По их мнению, расширительное толкование ЗИИГ чревато многочисленными юридическими проблемами, включая потенциальный конфликт с законом «О защите жертв пыток»; потенциальное освобождение иностранных чиновников от уголовной ответственности (ЗИИГ не делает различия между гражданской и уголовной юрисдикцией судов); отмену общеправовой доктрины, признающей абсолютный иммунитет глав иностранных государств; отмену иммунитетов бывших должностных лиц, а также необходимость для судов самим определять, какие действия являются «официальными», поскольку ЗИИГ не содержит положений на данный счет.

На стороне ответчиков выступили и трое американских законодателей (А. Спектр, Р. Файнголд и Ш. Джексон-Ли). По их мнению, распространение действия закона 1976 г. на физических лиц полностью лишило бы смысла закон «О защите жертв пыток», так как последний был принят Конгрессом с целью привлечь к ответственности иностранных лиц, применяющих пытки и внесудебные казни именно под прикрытием закона и властных полномочий.

Свою поддержку истцов засвидетельствовали и бывшие американские дипломаты, включая несколько экс-госсекретарей и послов. С их точки зрения, необходимость поддержания дружественных отношений между нациями вовсе не обязывает американские суды предоставлять всем без исключения бывшим иностранным чиновникам иммунитет.

Действительно, в определенных случаях разбирательство по искам против тех или иных иностранных чиновников не отвечает внешнеполитическим интересам США. Однако в таких случаях у судей есть другие, более гибкие механизмы отклонения иска, включая доктрины «политического вопроса» и «государственного акта».

Что же касается возможных негативных последствий решения в пользу ответчиков для иммунитетов американских чиновников за границей, то, по мнению бывших госдеповцев, официальные представители США и так достаточно защищены от неправомерных исков против них все теми же доктринами «государственного акта», «не подлежащего 
судебному рассмотрению политического вопроса», «разделения властей», «международной вежливости» и т.д.

Помимо этого, в крайних случаях может быть задействована эффективная американская дипломатия. Так, например, когда чрезмерно прогрессивное бельгийское и испанское законодательство разрешило своим судам осуществлять более широкую юрисдикцию в отношении бывших американских должностных лиц, чем это позволено международным правом, Вашингтон сумел добиться внесения необходимых поправок в иностранные законы.

Речь идет о бельгийском законе 1993 г. и об испанском законе 2005 г. об универсальной юрисдикции. На основании первого в бельгийские суды были поданы иски против Дж. Буша, К. Пауэлла и Д. Чейни. В ответ Вашингтон пригрозил перенести из Брюсселя штаб-квартиру НАТО. Помимо этого, в 2002 г. Международный суд в решении по делу «Об ордере на арест от 11 апреля 2000 г.» постановил, что, отказав в иммунитете действующему министру иностранных дел Конго, Брюссель нарушил обычное международное право. В итоге бельгийские законодатели были вынуждены внести поправки в свое законодательство.

На основании испанского закона были начаты уголовные расследования в отношении ряда американских должностных лиц из администрации Дж. Буша, обвинявшихся в санкционировании применения пыток к подозреваемым в терроризме лицам. В частности, бывшие заключенные Гуантанамо испанского происхождения подали иски против экс-министра юстиции США А. Гонсалеса, его зама Дж. Байби, минюстовца Дж. Ю и др. Однако в результате давления со стороны США, Израиля и Китая испанский Сенат в мае 2009 г. ограничил сферу охвата своего закона.

Даже после завершения устных прений по делу Самантара наблюдатели не решались предрешить его исход. Однако в итоге все девять членов Верховного суда единогласно пришли к заключению, что ЗИИГ неприменим к физическим лицам.

Судья Дж. Стивенс, написавший мнение суда, начал свою аргументацию с краткого описания истории доктрины иммунитета иностранного государства в американском праве.

Задолго до принятия закона 1976 г. иммунитеты регулировались в США общим правом. Самый ранний прецедент в этой 
области - решение Верховного суда 1812 г. по делу «Судно «Иксчендж» против Макфаддона» ${ }^{37}$.

После данного постановления решение вопроса о предоставлении иммунитета иностранному государству в конкретных случаях принималось американскими судами в два этапа. Если внешнеполитическое ведомство вступало в дело с заявлением о наличии иммунитета у ответчика, суд отказывался осуществлять свою юрисдикцию. Если оно сохраняло молчание, суд самостоятельно анализирован вопрос о наличии иммунитета, исходя из общего права и предыдущих рекомендаций исполнительной власти.

При этом в течение 140 лет после вынесения постановления по делу Макфаддона американские суды придерживались концепции абсолютного иммунитета иностранных государств. Только в 1952 г. и.о. юридического советника Госдепартамента США Дж. Тейт проинформировал Минюст об официальном переходе США на теорию ограниченного иммунитета.

Ситуация, которая сложилась в результате отказа от теории абсолютного иммунитета, создавала много неопределенности. Позиция внешнеполитического ведомства менялась от случая к случаю - в зависимости от сиюминутных политических соображений находящейся у власти администрации и давления со стороны государства-ответчика. В этом контексте в 1976 г. Конгресс США принял закон «Об иммунитете иностранных государств», чтобы «освободить Правительство от ... дипломатического давления, ... уточнить руководящие принципы, и ... заверить тяжущиеся стороны, что постановления будут приниматься исключительно на юридических основаниях и в соответствии с процедурой, гарантирующий справедливый судебный процесс» ${ }^{38}$. Далее судья Стивенс проанализировал текст закона 1976 г. и пришел к выводу, что хотя тот прямо и не запрещает применение данного нормативно-правового акта к должностным лицам, он и не поддерживает его.

${ }^{37}$ Schooner Exchange v. McFaddon, 7 Cranch 116 (1812). Судно, принадлежавшее американцам Дж. Макфаддону и У. Грифэму, было захвачено по приказу Наполеона и переоборудовано под французский военный корабль. В 1811 г., когда оно следовало из Европы и из-за непогоды было вынуждено зайти в американский порт, бывшие владельцы заявили на него свои претензии. Суд первой инстанции отклонил их иск, признав корабль собственностью французского правительства. Апелляционный суд отменил это решение, рассудив в пользу истцов, однако Верховный суд вновь встал на сторону Франции.

${ }^{38}$ Verlinden B.V. v. Cent. Bank of Nigeria, 461 U.S. 480, 486 (1983). 
На следующем этапе судья перешел к анализу целей закона «Об иммунитете иностранных государств». Он согласился, что одной из них была кодификация норм общего права в области иммунитетов иностранных государств. Однако из этого, по его мнению, вовсе не следует, что Конгресс также намеревался кодифицировать нормы, регулирующие иммунитеты иностранных официальных лиц. Как отметил судья, «смешать в одну кучу должностных лиц и сами иностранные государства без единого слова о том, как и когда именно эти лица покрываются иммунитетом, едва ли способствовало реализации цели Конгресса прояснить правила, которые судам надлежит применять, при разрешении вопросов о наличии иммунитета» ${ }^{39}$.

Никаких подтверждений позиции заявителя судья Стивенс не нашел и в материалах, посвященных истории принятия закона 1976 г. В принципе, в тот период проблема иммунитетов иностранных официальных представителей не стояла особенно остро, и законодателей не беспокоило, что данный вопрос решается внешнеполитическим ведомством (в отличие от вопросов о наличии иммунитета у самого государства, его подразделений и агентств).

В целом, по мнению судьи Стивенса, отношение между иммунитетами иностранного государства и его должностных лиц, сложнее, чем пытается представить заявитель. В этой связи он сослался на разъяснение в параграфе 66 Третьего свода права США в области международного права, согласно которому «иммунитет иностранного государства ... распространяется на ... дипломатического агента, должностного лица или агента этого государства в отношении действий, совершенных в официальном качестве, если результатом осуществления юрисдикиии будет приведение в действие нормы права против этого государства» (курсив - судьи Стивенса).

Таким образом, даже в тех случаях, когда должностное лицо не пользуется иммунитетом по общему праву, иск против него может быть отклонен, если иностранное государство является необходимой стороной дела и если рассмотрение дела без его участия может помешать ему защитить свой законный интерес ${ }^{40}$. В то же время иск против Самантара подан против него в личном качестве, нацелен на получение

\footnotetext{
${ }^{99}$ Mohamed Ali Samantar v. Bashe Abdi Yousuf et Al., Supreme Court of the United States. P. 16.

40 Там же. С.19.
} 
компенсации из его собственного кармана и, следовательно, должен регулироваться общим правом, а не ЗИИГ.

На этих основаниях Верховный суд подтвердил решение нижестоящих судов. При этом он неоднократно отметил, что его постановление не предрешает вопроса о наличии у Самантара иммунитета по общему праву, будь то доктрина иммунитета главы государства или какаялибо другая концепция. Этот вопрос, однако, должен решаться судом первой инстанции.

$$
* * *
$$

Большинство американских юристов с удовлетворением встретили решение Верховного суда. По их мнению, оно является результатом правильной интерпретации текста закона «Об иммунитетах иностранных государств» в контексте других законодательных актов и судебной практики ${ }^{41}$. Как отметила профессор Калифорнийского университета Ч. Кайтнер, судьи интерпретировали ЗИИГ так, как он есть, а не так, каким он должен быть. Даже один из авторов меморандума заявителя, профессор права К. Брэдли, назвал постановление «совершенно разумным толкованием текста ЗИИГ».

Тем не менее, по поводу решения было высказано и немало критических замечаний. Некоторые авторы были разочарованы тем, что постановление оставило нерешенными слишком много вопросов ${ }^{42}$, включая объем иммунитетов иностранных официальных лиц по общему праву, источник этого права (федеральное право, право штатов или иностранных государств), а также вопрос о том, как избежать потенциального «судебного шоппинга». Другие высказывали опасения, что в результате этого прецедента американские суды будут завалены исками против иностранных чиновников.

В целом, решение можно воспринимать как победу сторонников текстуального (буквального) толкования законодательства. Федеральные апелляционные суды, которые защищали позицию о применимости ЗИИГ к иностранным должностным лицам, явно основывались на телеологическом толковании закона. По их логике, буквальная

${ }^{41}$ См., например, мнения У. Доджа, Ч. Кейтнер, опубликованные на сайте http:// opiniojuris.org/2010/06/04/thoughts-on-samantar/.

${ }^{42}$ Таково мнение профессора школы права Университета шт. Джорджия и соавтора монографии «Международное гражданское судопроизводство в судах США» П. Рутледжа, http://opiniojuris.org/2010/06/04/thoughts-on-samantar/. 
интерпретация закона противоречит его целям, которые заключаются в сохранении гармоничных международных отношений, сведении до минимума давления иностранных государств и приведении американского законодательства в соответствие с международным правом.

Решение можно также рассматривать как победу исполнительной власти, которая всегда настаивала на том, что общее право иммунитетов иностранных официальных лиц продолжает действовать и после принятия закона 1976 г. ${ }^{43}$ При этом согласно заявлению amicus curiae, поданному правительством, эти иммунитеты регулируются «принципами, вырабатываемыми исполнительной властью».

Такой подход, безусловно, дает Госдепартаменту дополнительные рычаги воздействия на иностранных чиновников. Ссылаясь на свою компетенцию в решении сложных международных вопросов, он мог бы предоставлять иммунитет своим союзникам (по принципу «он, конечно, сукин сын, но наш сукин сын» $\left.{ }^{44}\right)$ и отказывать в нем представителям недружественных государств.

Вместе с тем некоторые юристы со скепсисом относятся к определяющей роли исполнительной власти в решении вопросов об иммунитете иностранных чиновников. Так, по мнению У. Доджа, вполне логично, что в компетенцию исполнительной власти входит определение того, кто пользуется дипиммунитетом и кого следует признавать в качестве легитимного главы иностранного государства. Гораздо более спорно, что администрация должна определять, являются ли пытки «официальным актом», в отношении которого действует иммунитет.

Особый интерес у юристов перед вынесением постановления Верховного суда вызывал также вопрос о соотношении закона «Об иммунитете иностранных государств» с законом «О защите жертв пыток». Сторонники «прогрессивного» развития американского права полагают, что как более поздний второй закон имеет преимущественную силу. Другие придерживаются позиции, что этот закон должен применяться без ущерба для иммунитетов, предоставляемых ЗИИГ.

В этой связи решение Верховного суда вряд ли можно трактовать как однозначную победу правозащитников. Оно никак не предрешает

43 Помимо многочисленных меморандумов исполнительной власти, подготовленных для представления суду по различным делам, такая позиция излагается в одной из заметок бывшего руководителя правовой службы Госдепартамента Дж. Беллинджера, размещенных в январе 2007 г. в блоге “Opinio Juris”, http://www.state.gov/s/1/2007/116111. htm.

${ }^{44}$ Известная фраза Ф.Рузвельта в отношении никарагуанского диктатора А. Сомосы. 
вопроса о том, аннулирует ли закон «О защите жертв пыток» иммунитеты иностранных чиновников по общему праву. Напротив, после июньского постановления нижестоящие суды едва ли смогут игнорировать вопрос о потенциальном наличии иммунитета у официальных лиц иностранных государств, как они порой это делали в прошлом ${ }^{45}$.

\section{Библиографический список.}

Bederman, D.J. Dead's Man's Hand: Reshuffling Foreign Sovereign Immunities in U.S. Human Rights Litigation // Georgia Journal of International \& Comparative Law. No. 25 (1995-1996). P. 255-285.

Bradley C. Foreign Officials and Sovereign Immunity in U.S. Courts // ASIL Insight. Vol. 13, Issue 3. March 17, 2009. URL: www.asil.org/ insights090317.cfm (дата обращения: 1 ноября 2010 г.)

Bradley C. and Goldsmith J. Foreign Sovereign Immunity, Individual Officials, and Human Rights Litigation // 13 Green Bag 2d. Vol. 13. C. 9 (2009), URL: http://ssrn.com/abstract=1485667 (дата обращения: 1 ноября 2010 г.)

Fox, H. The law of state immunity, Oxford-New York: Oxford University Press, 2d ed. 2008. 455 p.

George, S.V. Head of State Immunity in the US Courts: Still Confused After All These Years // Fordham Law Review. Vol. 64. 1995. P. 1051-1088.

Keitner Ch. Officially Immune? A Response to Bradley and Goldsmith // The Yale Journal of International Law Online. Vol. 36. Spring 2010. URL: www.yjil.org/online/volume-36-spring-2010/ (дата обращения: 1 ноября 2010 г.)

Murphy, S.D. Head-of-State Immunity for Former Chinese President Jiang Zemin // American Journal of International Law. Vol. 7. 2003. P. 974977.

Restatement (Third) of the Foreign Relations Law of the United States. St. Paul: American Law Institute Publishers. 1987. Vol. 1-2.

Sovereign Immunity Decisions of the Department of State, May 1952 to January 1977 (M. Sandler, D. Vagsts, and B. Ristau, eds.) // 1977 Digest of U.S. Practice in International Law. 1017. P.1017.

Stewart D. Samantar v. Yousuf: Foreign Official Immunity Under Common Law // ASIL Insights. Vol. 14. Issue 15. June 14, 2010. URL: www.asil.org/insights 100614.cfm (дата обращения: 1 ноября 2010 г.)

${ }^{45}$ Например, в деле «Филартига против Пенья-Илара». 


\section{The U.S. Supreme Court Decision in the Case Samantar v. Yousuf and Immunities of Foreign Officials \\ (Summary)}

\section{Svetlana V. Shatalova*}

The article is devoted to the U.S. Supreme Court decision of June 1, 2010 in the case Samantar v. Yousuf, which authoritatively resolved the issue of the source of legal norms regulating the immunities of foreign officials in the U.S. law. Prior to the judgment, different federal courts of appeals gave different interpretation to the question, whether the 1976 Foreign Sovereign Immunities Act applies to representatives of other States acting in their official capacity. As a result of this legal uncertainty, foreign governmental officers in U.S. courts received different treatment in terms of immunities in almost identical situations. The Supreme Court judgments being binding on all the lower U.S. courts, the case of the Somali general Mohamed Samantar provoked a vivid reaction in the country's legal community, as well as in a number of foreign States. The article explains different legal views presented to the U.S. Supreme Courts by the lawyers of the petitioner, respondents, Government and third parties. It summarizes the argumentation by the Court and analyses the bearing that the June decision may have for the development of the U.S. law of immunities.

Keywords: Jurisdictional immunities; foreign officials; common law; foreign head of State immunity.

*. Svetlana V. Shatalova - Third Secretary of the Russian Embassy in the U.S.A. taurussvet@ hotmail.com. 